\title{
Assessment of phytochemical screening by Fourier Transform Infrared spectroscopic analysis of peach (Prunus persica) seed biomass from Uttarakhand region of India
}

\author{
Rishi Kumar Shukla \\ Department of Chemistry, Gurukula Kangri Vishwavidyalaya, Haridwar - 249404 (Uttarakhand), \\ India \\ Ravi Kant \\ Department of Chemistry, Gurukula Kangri Vishwavidyalaya, Haridwar - 249404 (Uttarakhand), \\ India \\ "Corresponding author. E-mail: ravikant0388@gmail.com
}

\author{
Article Info \\ https://doi.org/10.31018/ \\ jans.v12i4.2330 \\ Received: July 30, 2020 \\ Revised: November 4, 2020 \\ Accepted: November 18, 2020
}

\section{How to Cite}

Shukla R. K. and Kant R. (2020). Assessment of phytochemical screening by Fourier Transform Infrared spectroscopic analysis of peach (Prunus persica) seed biomass from Uttarakhand region of India. Journal of Applied and Natural Science, 12(4): 519524. https://doi.org/10.31018/jans.v12i4.2330

\begin{abstract}
Prunus persica (Peach) has several medicinal and nutritive properties such as antioxidant, antimalarial, anticoagulant, antifungal, ant-allergic, etc. The present study focuses on the exploratory for phytochemicals constituents screening of seed extracts of Prunus persica from Uttarakhand region of India by Fourier Transform Infrared spectroscopy (FTIR) analysis. The extraction of seed was carried out using soxhlet apparatus in different solvents such as petroleum ether, chloroform, ethyl acetate, ethand, and water. The characteristics of physical parameters of dried seed of $P$. persica were reported as total ash $(14.250 \pm 0.126 \%)$, acid insoluble ash $(6.800 \pm 0.036 \%)$, water-soluble ash $(11.714 \pm 0.123 \%)$, and sulphated ash value $(2.274 \pm 0.025 \%)$; whereas, the extractive values were also recorded as alcohol soluble extractive $(1.917 \pm 0.011 \%)$, and water-soluble extractive $(10.580 \pm 0.048 \%)$. The highest values of nutritive components $(366.778 \pm 0.257 \%)$ were followed by, carbohydrate $(45.500 \pm 0.336 \%)$, crude protein $(29.360 \pm 0.551 \%)$, available carbohydrate content $(28.002 \pm 0.439 \%)$, moisture content $(12.547 \pm 0.022 \%)$, crude fibre $(11.602 \pm 0.123 \%)$, crude fat $(7.482 \pm 0.068 \%)$, and total nitrogen $(4.695 \pm 0.032 \%)$. The maximum extraction yield was recorded in the aqueous extract solution ( $11.15 \%)$, followed by petroleum ether (2.8\%), ethyl acetate $(2.1$ $\%$ ), ethanol (1.6\%), and chloroform (0.4\%). Besides, this the most effective chemical bonding groups of FTIR spectra analyzed in a sample of $P$. persica seed were N-H, O-H (3600-3400 1/cm), C-H $(3000-28001 / \mathrm{cm}), \mathrm{N}-\mathrm{H}, \mathrm{C}-\mathrm{C}, \mathrm{C}=\mathrm{O}(1680-15501 / \mathrm{cm}), \mathrm{C}-$ H (1470-1350 1/cm), CO-OR (1400-1000 1/cm), C-H (850-550 1/cm), and C-I $(500-4001 / \mathrm{cm})$, respectively. Therefore, this study provides useful insights into the beneficial properties of $P$. persica seed biomass from the Uttarakhand region of India, which may be further used for the production of several pharmaceuticals and nutraceutical products.
\end{abstract}

Keywords: Extraction process, FTIR analysis, P. persica seed, Phytochemical screening

\section{INTRODUCTION}

The Prunus persica is commonly known as Peach, which is cultivated since the $19^{\text {th }}$ century in India. Its seed has been reported for its several medicinal properties such as antioxidant, antimalarial, anticoagulant, antifungal, ant-allergic, etc. (Cao et al., 2014; Kant et al., 2018). Traditionally, its leaves were used for healing sores and wounds, for the treatment of coughs, bronchitis, and abdominal disorders. $P$. persica leaves have a broad range of vital nutrients and antioxidants for the healthy functioning of the human body (Kim et al., 2014; Maatallah et al., 2020). Peach seed extract is found to be useful against different disorders like chronic diarrhoea, dysentery, and chronic hepatitis. Due to the relatively lower incidence of adverse reac- tions of leave extract in comparison with synthetic agents, it is widely exploited as an attractive eco-friendly alternative for antimicrobial drugs (Rani et al., 2016).

$P$. persica is deciduous tree up to $10 \mathrm{~m}$ in height naturally distributed throughout temperate regions originally from Asia and Southern Europe (Gaur, 1999). It belongs to the family Rosaceae and commonly known as "Aaru" in Hindi and "Peach" English. Peach has an important place in human nutrition and can be used as fresh, dried, or processed fruit. Peaches are nutritionally and economically essential, and they are one of the most popular fruits consumed worldwide (Zhao et al., 2015).

The bark of peach is greyish or ashy acuminate glabrous usually utilized in cough, whooping cough, chronic bronchitis, sedative, stomachic, demulcent, 
anti-scorbutic, diuretic (Raturi et al., 2011). Its flowers are pinkish-white sessile, short, and pedicelled. Green color leaves are very useful as astringent, demulcent, diuretic, expectorant, febrifuge, laxative, and parasiticide and are seductive (Raturi et al., 2011; Zhao et al., 2015). The fruits have usually a clear ventral suture, do not retain floral residues next to the pedicel, and are characterized by a membranous exocarp with an outer fleshy mesocarp consisting mainly of parenchyma cells (Kim et al., 2014). The mesocarp surrounds a shell (the pit or stone) of hardened endocarp with a seed inside and due to this genus Prunus is also referred to as "stone fruit". In almonds, the consumed portion is the seed within the pit, while the edible part in most stone fruits includes the mesocarp, and eventually, the exocarp (Shukla et al., 2012). Peaches, along with cherries plums and apricots are stone fruits (drupes). The single, broad seed is red-brown, around $1.3-2.0 \mathrm{~cm}$ long, oval and is enclosed by a wood-like husk. Varieties of heirlooms are available, such as the Indian Peach or Indian Blood Peach, and these arrive in the late summer ranging from red to white to purple. The purpose of this study was aimed at the phytochemical estimation of $P$. persica. In addition, the nutrient values and proximate compositions of $P$. persica were also assessed.

\section{MATERIALS AND METHODS}

Collection of $\boldsymbol{P}$. persica seed: For the present study, the $P$. persica seed was collected from the Rani Pokhri Rishikesh (30¹0'52.4"N 78¹2'38.2"E), Uttarakhand. The collected sample of $P$. persica (seed) was verified by the Botanical Survey of India, Dehradun with accession No.116191. A verified voucher specimen has also been submitted in medicinal plants herbarium of the Department of Chemistry, Gurukula Kangri Vishwavidyalaya, Haridwar. The collected seeds were washed and shade dried followed by grinding for the preparation of fine mash. The fine mesh was used in further analysis of physical evaluation (ash, extractive value) and proximate analysis viz., moisture content or loss of drying, total nitrogen, crude protein, crude fat, crude fibre, total carbohydrate content, available carbohydrate content, and nutritive values.

Preparation of seed extracts: The extraction of seed extracts was carried out using soxhlet extraction method by different solvents viz., petroleum ether $\left(\mathrm{C}_{6-16} \mathrm{H}_{12-}\right.$ 34), chloroform $\left(\mathrm{CH}: \mathrm{CHCl}_{3}\right)$, ethyl acetate $\left(\mathrm{EA}: \mathrm{C}_{4} \mathrm{H}_{8} \mathrm{O}_{2}\right)$, ethanol (PE: $\left.\mathrm{C}_{2} \mathrm{H}_{5} \mathrm{OH}\right)$ and aqueous $\left(\mathrm{AQ}: \mathrm{H}_{2} \mathrm{O}\right)$ in the way of increasing polarity. Extraction of the seed done through at least 60 cycles of siphoning was completed with each solvent and extraction was continued until siphon tube became colourless. Seed extracts were concentrated using a rotary vacuum evaporator and refrigerated for further use (Nakagawa et al., 2018).

Physical parameters estimation of $P$. persica seed: The estimation of physical characteristics of $P$. persica seed viz., ash, total ash, acid insoluble, water -soluble ash, and sulphated ash was done, and on the other hand, the extractive values were determined in the form of water-soluble and alcohol soluble also examined. The values of physical characteristics of $P$. persica seed are reported in ash value and extractive value and their sub-parameters. These parameters were subjected to quantitative test analysis using the standard method (Kumar and Chaudhary, 2017).

Proximate analysis and nutritive values of $\boldsymbol{P}$. persica seed: The proximate analysis of the above mashed $P$. persica seed was performed by the percentage $(\%)$ estimation of moisture content, crude protein, crude fibre, total nitrogen content, and crude fat, following standard method AOAC (2005). Further, the rest parameters were calculated using the equation:

Total Carbohydrate $=100-(\%$ Ash $+\%$ Moisture $+\%$ Crude fibre $+\%$ Crude protein) $\quad$.........(Eq. 1) The nutritive value was expressed in kilocalories/100 $\mathrm{g}$ of the dry weight of leaves, which was calculated as nutritive value (NV).

$\mathrm{NV}($ Kcal $/ 100 \mathrm{gm})=(4 \times \%$ protein $)+(9 \times \%$ Crude fat $)+(4$ $\mathrm{x} \%$ total Carbohydrate) $\quad$.........(Eq. 2 ) Total nitrogen (\%) was determined by the well-known Kjeldahl method, and their relative crude protein (RCP) calculated by following formula as:

$\mathrm{RCP}=(\% \mathrm{~N} \times 6.25)$

Phytochemical analysis of $\boldsymbol{P}$. persica seed extract: Phytochemical analysis for various phytoconstituents (alkaloids, carbohydrate, glycosides, inulin, protein, steroids/triterpenoids, fixed oils and fats, flavonoids, phenolic, compound and tannins, gums and mucilage) of the seed extracts was determined using standard qualitative methods. The obtained extracts were screened for the presence of different metabolites viz., tannins, saponins, phlobatanins, flavonoids, terpenoids, cardiac glycosides, and alkaloids (Kumar and Chaudhary, 2017).

Analysis of FTIR peaks of $\boldsymbol{P}$. persica seed sample The Fourier Transform Infrared Spectrophotometer (FTIR) is feasibly the utmost influential instrument for recognizing the forms of element bonds (functional groups) existing in the samples. The wavelength of light immersed is distinctive of the chemical bond as can be seen in the illustration bands. By understanding the infrared immersion spectrum, the chemical bonds in a molecule can be analyzed. Dried powder of $P$. persica seed was used for the FTIR examination. 10 $\mathrm{mg}$ of the dried extract powder was summarized in 100 $\mathrm{mg}$ of $\mathrm{KBr}$ pellet, to make clean sample discs. The powdered sample of translucent was loaded in FTIR spectroscope, with an analyzed range from 400 to $4000 \mathrm{~cm}^{-1}$ (Ashokkumar and Ramaswamy, 2014).

\section{RESULTS AND DISCUSSION}

Estimation of physical parameters (\%) of $P$. persica seed: The results of the physical characteristics of $P$. persica seed are presented in Table 1.. In physical parameters the selected parameters are described as 
total ash value $(14.250 \pm 0.126 \%)$, acid insoluble ash $(6.800 \pm 0.036 \%)$, water-soluble ash $(11.714 \pm 0.123 \%)$, and sulphated ash value $(2.274 \pm 0.025 \%)$; whereas, the extractive values are recorded as alcohol soluble extractive $(1.917 \pm 0.011 \%)$, and water-soluble extractive $(10.580 \pm 0.048 \%)$, respectively. The findings of the present study are in line with Ashraf et al., (2011) who reported similar results of nutritional and physicochemical studies on fruit pulp, seed, and shell of indigenous Prunus persica. Zhang et al. (2020) also reported the results of the physical characteristics of $P$. persica by UPLC-Q-TOF/MS-based metabolomics methods.

Assessment of proximate composition of $\boldsymbol{P}$. persica seed: The proximate examination encompasses the mass percentages of moisture, ash, volatile matter, and fixed carbon, etc. Table 2 shows the proximate composition of $P$. persica. It is characterized by nutritive values $(366.778 \pm 0.257 \%)$, followed by carbohydrate $(45.500 \pm 0.336 \%)$, crude protein $(29.360 \pm 0.551 \%)$, available carbohydrate content $(28.002 \pm 0.439 \%)$, moisture content $(12.547 \pm 0.022 \%)$, crude fibre $(11.602 \pm 0.123 \%)$, crude fat $(7.482 \pm 0.068 \%)$, and total nitrogen (4.695 $\pm 0.032 \%)$. Similarly, Qumar (2016) also investigated that the different proximate values of $P$. persica during the study of nutritional constituents and sensory evaluation of bakery products prepared from seed and bark of prunus persica (peach). The results by Kumari et al. (2017) also showed that the seed of $P$. persica is a good source of protein, fat and crude fiber, high carbohydrate and other constitutes a major class of naturally occurring organic compounds that are essential for the maintenance of plant and animal life and also

Table 1. Characterization of physical parameters of the dried seed of $P$. persica.

\begin{tabular}{lll}
\hline Parameter & Sub-parameter & $\%^{*}$ \\
\hline \multirow{4}{*}{ Ash value } & Total ash value & $14.250 \pm 0.126$ \\
& Acid insoluble ash & $6.800 \pm 0.036$ \\
& Water soluble ash & $11.714 \pm 0.123$ \\
& Sulphated ash value & $2.274 \pm 0.025$ \\
Extractive & Alcohol soluble & $1.917 \pm 0.011$ \\
value & extractive value & \\
& Water soluble & $10.580 \pm 0.048$ \\
\hline
\end{tabular}

*Values presented in the table are the mean \pm SD of three replicates.

Table 2. Proximate composition of dried seed of $P$. persica.

\begin{tabular}{ll}
\hline Parameter & $\%^{*}$ \\
\hline Moisture content or loss of drying & $12.547 \pm 0.022$ \\
Total nitrogen & $4.695 \pm 0.032$ \\
Crude protein & $29.360 \pm 0.551$ \\
Crude fat & $7.482 \pm 0.068$ \\
Crude fibre & $11.602 \pm 0.123$ \\
Total carbohydrate content & $45.500 \pm 0.336$ \\
Available carbohydrate content & $28.002 \pm 0.439$ \\
Nutritive value $^{*}$ & $366.778 \pm 0.257$ \\
\hline
\end{tabular}

*Values are expressed as mean $\pm S D$ of the three replicates. ${ }^{*}$ Nutritive value is calculated in kcal/100 g dry weight of leaves. SD: Standard deviation. provide raw materials for many industries.

Evaluation of extractive yield of $\boldsymbol{P}$. persica seed: The percentage extractive yield of $P$. persica seed was presented in Table 3.. The maximum extraction yield was recorded in the aqueous extract solution $(11.15 \%)$, followed by petroleum ether $(2.8 \%)$, ethyl acetate $(2.1 \%)$, ethanol $(1.6 \%)$, and chloroform $(0.4$ $\%)$. The findings of the present study are according to Altemimi et al. (2017) who reported extractive yield from selected plant biomass with reference to phytochemicals: extraction, isolation, and identification of bioactive compounds from plant extracts. During the present experimental study, the different yield of extracts from the selected plant material in various solvents confirms the solubility of plant chemical ingredients in different solvents thus signifying the best solvent for extraction of phytochemicals. Altemimi et al. (2015) has reported the maximum extractive value from $P$. persica seed in solvents of high polarity which is indicative of the occurrence of polar compounds in greater quantity.

Phytochemical analysis of $\boldsymbol{P}$. persica seed: The assessment of qualitative phytochemical examination of Prunus persica seed showed the occurrence of different compositions viz., alkaloids, steroids, terpenoids, flavonoids, phenolic, tannins, saponins, glycosides, carbohydrates, and proteins in different extracts as presented in Table 4. These tests were performed by the different solutions of petroleum ether (PE), chloroform $(\mathrm{CH})$, ethyl acetate (EA), ethanol (ET), and aqueous (AQ). Similarly, Kumar and Chaudhary (2017) also investigated the different phytochemical compositions of $P$. persica using various tests. From their findings, it was confirmed from the phytochemical analysis of $P$. persica that several carbohydrates, inulin, and flavonoids were present its extract. The other study also confirmed that plant extract compounds are responsible for several biological functions in the human body, therefore have a great pharmaceutical application (Tungmunnithum et al., 2018).

Phytochemical screening by FTIR spectroscopic analysis of $\boldsymbol{P}$. persica seed: The determination of phytochemical constituents of $P$. persica using FTIR spectroscopic analysis indicated the presence of highly chemical bonding compounds viz., $\mathrm{N}-\mathrm{H}, \mathrm{O}-\mathrm{H}, \mathrm{C}-\mathrm{H}$, $\mathrm{N}-\mathrm{H}, \mathrm{C}-\mathrm{C}, \mathrm{C}=\mathrm{O}, \mathrm{C}-\mathrm{H}, \mathrm{CO}-\mathrm{OR}, \mathrm{C}-\mathrm{H}, \mathrm{C}-\mathrm{I}$ (overlapping and stretching of amides, crude protein, carbohydrates; alkyl chain; unconjugated alkenes, carbohydrates, crude protein; bending cyclic alkenes; alicylclic compounds, aromatic hydrocarbons and saccharides of seed cuticle organo-iodides. The wavenumber group $(1 / \mathrm{cm})$ of the spectrum of $P$. persica seed biomass are presented in Table 5. The selected peaks were ranged from 400 to $4000 \mathrm{~cm}^{-1}$ in respect of overlapping and stretching of amides, crude protein, carbohydrates, alkyl chain, unconjugated alkenes, carbohydrates, bending cyclic alkenes, alicyclic compounds, aromatic hydrocarbons, saccharides of seed cuticle, and organoiodides. The interpretation of 
Table 3. Percentage yield and colour of concentrated different seed extracts of $P$. persica.

\begin{tabular}{lllll}
\hline Extract & $\begin{array}{l}\text { Weight of } \\
\text { sample }\end{array}$ & Weight of extract $(\mathbf{g m})$ & $\begin{array}{l}\text { \%Yield } \\
(\mathbf{w} / \mathbf{w})\end{array}$ & Colour \\
\hline Petroleum ether (PE) & $200 \mathrm{gm}$ & 5.6 & 2.8 & Light yellow \\
Chloroform (CH) & $200 \mathrm{gm}$ & 0.8 & 0.4 & Brownish \\
Ethyl acetate (EA) & $200 \mathrm{gm}$ & 4.2 & 2.1 & Brownish \\
Ethanol (ET) & $200 \mathrm{gm}$ & 3.2 & 1.6 & Dark Brown \\
Aqueous (AQ) & $200 \mathrm{gm}$ & 22.3 & 11.15 & Dark Black \\
\hline
\end{tabular}

Table 4. Phytochemical constituents of $P$. persica seed extract.

\begin{tabular}{|c|c|c|c|c|c|c|c|}
\hline \multirow{2}{*}{ Phytoconstituents } & & \multicolumn{6}{|c|}{ Test performed } \\
\hline & & & PE & $\mathrm{CH}$ & EA & ET & $\mathbf{A Q}$ \\
\hline \multirow{4}{*}{ Alkaloids } & \multicolumn{2}{|l|}{ Mayer's Test } & - & + & + & - & - \\
\hline & \multicolumn{2}{|l|}{ Wagner's Test } & - & - & - & - & - \\
\hline & \multicolumn{2}{|l|}{ Hager's Test } & - & - & - & - & - \\
\hline & \multicolumn{2}{|l|}{ Tannic acid Test } & - & - & - & - & - \\
\hline & \multicolumn{2}{|l|}{ Molisch 's Test } & - & + & + & + & + \\
\hline \multirow[t]{4}{*}{ Carbohydrate } & \multicolumn{2}{|l|}{ Benedict's Test } & - & - & + & + & + \\
\hline & \multicolumn{2}{|l|}{ Selivanoff's Test } & - & - & - & - & - \\
\hline & Anthraquinone & Borntrager's Test & - & - & - & - & - \\
\hline & glycosides & Hydroxy-nthraquinones & - & - & - & - & - \\
\hline \multirow[t]{3}{*}{ Glycosides } & & Keller-Killiani Test & + & + & + & + & ++ \\
\hline & Cardiac & Legal's Test & - & - & + & + & + \\
\hline & glycosides & Baljet's Test & - & - & - & + & + \\
\hline \multirow[t]{2}{*}{ Inulin } & & & + & + & ++ & ++ & ++ \\
\hline & \multicolumn{2}{|l|}{ Heat Test } & - & - & - & - & - \\
\hline \multirow[t]{2}{*}{ Protein } & \multicolumn{2}{|c|}{ Biuret Test } & - & - & - & - & - \\
\hline & \multicolumn{2}{|c|}{ Xanthoproteic Test } & - & + & + & ++ & ++ \\
\hline $\begin{array}{l}\text { Steroids/ } \\
\text { Triterpenoids }\end{array}$ & \multicolumn{2}{|l|}{ Salkowski Test } & - & $+(\mathrm{T})$ & $+(T)$ & $+(\mathrm{S})$ & - \\
\hline \multirow[t]{2}{*}{ Fixed oils and Fats } & \multicolumn{2}{|l|}{ Spot Test } & - & - & - & - & - \\
\hline & \multicolumn{2}{|c|}{ Shinoda Test } & + & - & + & - & - \\
\hline \multirow[t]{2}{*}{ Flavonoids } & \multicolumn{2}{|c|}{ Alkaline reagent Test } & + & + & ++ & ++ & ++ \\
\hline & \multicolumn{2}{|c|}{ Zinc hydrochloride Test } & - & - & - & + & ++ \\
\hline Phenolic & \multicolumn{2}{|c|}{ Ferric chloride Test } & - & - & ++ & ++ & - \\
\hline $\begin{array}{l}\text { Compound } \\
\text { and Tannins }\end{array}$ & \multicolumn{2}{|c|}{ Test for Chlorogenic acid } & - & - & - & - & - \\
\hline \multicolumn{3}{|l|}{ Gums and Mucilage } & - & - & - & - & - \\
\hline
\end{tabular}

+: Present; - : Absent; PE: Petroleum ether; $\mathrm{CH}$ : Chloroform; EA: Ethyl acetate; ET: Ethanol; AQ: Aqueous; and (T): Triterpenoids; (S): Steroids.

marked FTIR peaks of the spectrum of $P$. persica seed biomass (quantity $=1 /$ transmittance) are shown in Fig. 1. The present study observed the most effective chemical bonding groups in the analyzed sample of $P$. persica seed viz., N-H, O-H (3600-3400 1/cm), C-H (3000-2800 1/cm), N-H, C-C, C=O (1680-1550 1/cm), $\mathrm{C}-\mathrm{H}(1470-1350$ 1/cm), CO-OR (1400-1000 1/cm), C$\mathrm{H}(850-5501 / \mathrm{cm})$, and C-I (500-400 1/cm). Ashok kumar and Ramaswamy (2014) did the phytochemical screening using FTIR spectroscopic analysis of leaf extracts of selected Indian medicinal plants, whereas Jiao et al. (2019) also studied that the preparation of a chitosan-chlorogenic acid conjugate and its application as edible coating in postharvest preservation of peach

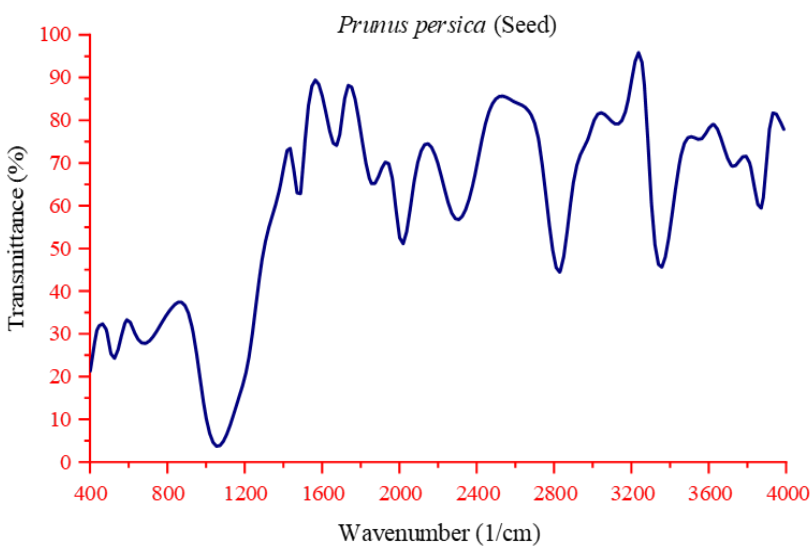

Fig. 1. FTIR peaks of Prunus persica seed biomass. 
Table 5. Interpretation of marked FTIR peaks of the spectrum of $P$. persica seed biomass (Quantity $=1 /$ Transmittance).

\begin{tabular}{|c|c|c|c|c|c|}
\hline $\begin{array}{l}\text { Wavenumber } \\
\text { group }(1 / \mathrm{cm})\end{array}$ & $\begin{array}{l}\text { Analyzed } \\
\text { peak }(1 / \mathrm{cm})\end{array}$ & $\begin{array}{l}\text { Transmittance } \\
(\%)\end{array}$ & $\begin{array}{l}\text { Bonding } \\
\text { groups }\end{array}$ & Compounds & Reference \\
\hline $3600-3400$ & 3566.21 & 75.82 & $\mathrm{~N}-\mathrm{H}, \mathrm{O}-\mathrm{H}$ & $\begin{array}{l}\text { Overlapping and stretching } \\
\text { of amides, Crude protein, } \\
\text { Carbohydrates }\end{array}$ & Jiao et al. (2019) \\
\hline $3000-2800$ & 2899.76 & 75.41 & $\mathrm{C}-\mathrm{H}$ & Alkyl chain & $\begin{array}{l}\text { Sivapriya and } \\
\text { John (2019) }\end{array}$ \\
\hline $1680-1550$ & 1621.92 & 81.27 & $\mathrm{~N}-\mathrm{H}, \mathrm{C}-\mathrm{C}, \mathrm{C}=\mathrm{O}$ & $\begin{array}{l}\text { Unconjugated } \\
\text { alkenes, Carbohydrates, } \\
\text { Crude protein }\end{array}$ & $\begin{array}{l}\text { Ashokkumar and } \\
\text { Ramaswamy } \\
(2014)\end{array}$ \\
\hline $1470-1350$ & 1435.34 & 73.44 & $\mathrm{C}-\mathrm{H}$ & Bending cyclic alkenes & $\begin{array}{l}\text { Sivapriya and } \\
\text { John (2019) }\end{array}$ \\
\hline $1400-1000$ & 1001.08 & 10.22 & CO-OR & $\begin{array}{l}\text { Alicylclic compounds, } \\
\text { Aromatic hydrocarbons }\end{array}$ & $\begin{array}{l}\text { Victoria Fer- } \\
\text { na'ndez et al. } \\
\text { (2019) } \\
\text { Ashokkumar and }\end{array}$ \\
\hline $850-550$ & 590.23 & 27.3 & $\mathrm{C}-\mathrm{H}$ & Saccharides of seed cuticle & $\begin{array}{l}\text { Ramaswamy } \\
\text { (2014) }\end{array}$ \\
\hline $500-400$ & 401.20 & 25.33 & C-I & Organoiodides & $\begin{array}{l}\text { Jamila et al. } \\
\text { (2019) }\end{array}$ \\
\hline
\end{tabular}

fruit. Kumar et al. (2020) discussed different marked peaks associated with the presence of phytochemically active compounds in sesame plant biomass. Acquah et al. (2016) studied the FTIR spectra of $P$. persica seed and found that it had numerous bonding groups which were associated with the presence of different phytochemical compounds. Out of them, the majority of identified peaks were $600,900,1190,1200$, $1440,1500,1620$, and $18001 / \mathrm{cm}$, respectively. The most occurring bonding groups were $\mathrm{C}-\mathrm{O}$ and $\mathrm{C}=\mathrm{O}$ associated with compounds containing conjugated aromatic ketones and stretching vibration in flavone, respectively.

\section{Conclusion}

This study assessed the phytochemistry and nutritional values of $P$. persica seed biomass in Uttarakhand. Since different climatic regions have a significant effect on the phytochemistry of the same plant, therefore, our work presents new findings for this region. It was found that $P$. persica seed biomass was characterized by reasonable quantities of alkaloids, steroids, terpenoids, flavonoids, phenolic, tannins, saponins, glycosides, carbohydrates, and proteins. Also, the nutritive values (nutritive components of $366.778 \pm 0.257$, carbohydrate of $45.500 \pm 0.336 \%$, crude protein of $29.360 \pm 0.551 \%$, the available carbohydrate content of $28.002 \pm 0.439 \%$, moisture content of $12.547 \pm 0.022 \%$, the crude fibre of $11.602 \pm 0.123 \%$, crude fat of $7.482 \pm 0.068 \%$, and total nitrogen of $4.695 \pm 0.032 \%$ ) of $P$. persica were also higher in this region than other previously carried studies out in various researches. These results might be due to climatic variations of Uttarakhand region, which may actively affect the plant response and its phytochemical compositions. FTIR analysis results suggested that the phytochemical extracts of $P$. persica seed had several bonding groups responsible for the presence of various phytoactive compounds which further may be used for the production of pharmaceutical and nutraceutical products.

\section{ACKNOWLEDGEMENTS}

This research work was supported by the Department of Chemistry, Gurukula Kangri Vishwavidyalaya, Haridwar, India. The University Grants Commission, New Delhi, India is acknowledged for providing the UGC National Fellowship [Grant number F1-17.1/2017-18/RGNF-201718-SC-UTT-32528 /(SA-III/Website) to Ravi Kant.

\section{Conflict of interest}

The authors declare that they have no conflict of interest.

\section{REFERENCES}

1. Acquah, G. E., Via, B. K., Fasina, O. O. and Eckhardt, L. G. (2016). Rapid quantitative analysis of forest biomass using fourier transform infrared spectroscopy and partial least squares regression. Journal of Analytical Methods in Chemistry, ID:1839598: 1-11. https://doi.org/10.1155/201 $6 / 1839598$

2. Altemimi, A., Lakhssassi, N., Baharlouei, A., Watson, D.G. and Lightfoot, D.A. (2017). Phytochemicals: Extraction, isolation, and identification of bioactive compounds from plant extracts. Plants, 6(4): 42. https://doi.org/10.3390/ plants6040042

3. Altemimi, A.W., Watson, D.G., Kinsel, M. and Lightfoot, D.A. (2015). Simultaneous extraction, optimization, and analysis of flavonoids and polyphenols from peach and pumpkin extracts using a tlc-densitometric method. Chemistry Central Journal, 9: 1-15. https://doi.org/10.1186/ s13065-015-0113-4

4. AOAC. (2005). Official methods of analysis of the association of official analytical chemists. 13th ed. Rockville (MD): AOAC International; 2005; p. 545-567.

5. Ashokkumar, R. and Ramaswamy, M. (2014). Phytochemical screening by FTIR spectroscopic analysis of leaf extracts of selected Indian medicinal plants. International Journal of Current Microbiology and Applied Sciences, 3 (1): 395-406.

6. Ashraf, C.M., lqbal, S. and Ahmed, D. (2011). Nutritional and physicochemical studies on fruit pulp, seed and shell of indigenous Prunus persica. Journal of Medicinal Plants 
Research, 5(16): 3917-3921.

7. Cao, K., Zheng, Z., Wang, L., Liu, X., Zhu, G., Fang, W. and Xie, M. (2014). Comparative population genomics reveals the domestication history of the peach, Prunus persica, and human influences on perennial fruit crops. Genome Biology, 15(7): 415, https://doi.org/10.1186/ s13059-014-0415-1

8. Gaur, R.D. (1999). Flora of the District Garhwal, North West Himalaya. Transmedia.http://agris.fao.org/agrissearch/search.do?recordID=US201300069963

9. Jamila, N., Khan, N., Hwang, I. M., Saba, M., Khan, F., Amin, F. and Ullah, F. (2019). Characterization of natural gums via elemental and chemometric analyses, synthesis of silver nanoparticles, and biological and catalytic applications. International journal of biological macromolecules. International Journal of Biological Macromolecules. https://doi.org/10.1016/j.ijbiomac.2019.09.245

10.Jiao, W., Shu, C., Li, X., Cao, J., Fan, X. and Jiang, W. (2019). Preparation of a chitosan-chlorogenic acid conjugate and its application as edible coating in postharvest preservation of peach fruit. Postharvest Biology and Technology, 154: 129-136. https://doi.org/10.1016/ j.postharvbio.2019.05.003

11.Kant, R., Shukla, R. K. and Shukla, A. (2018). A review on Peach (Prunus persica): an asset of medicinal phytochemicals. International Journal for Research in Applied Science \& Engineering Technology, 6(I): 2186-2200. https://doi.org/10.22214/ijraset.2018.1342

12.Kim, H. R., Kim, I. D., Dhungana, S.K., Kim, M. O. and Shin, D. H. (2014). Comparative assessment of physicochemical properties of unripe peach (Prunus persica) and Japanese apricot (Prunus mume). Asian Pacific Journal of Tropical Biomedicine, 4(2): 97-10., https:// doi.org/10.1016/S2221-1691(14)60216-1

13.Kumar, N. and Chaudhary, A. (2017). Pharmacognostic and phytochemical evaluation of Prunus persica (L.). International Journal of Research and Development in Pharmacy \& Life Sciences, 6: 2806-2812. https:// doi.org/10.21276/ijrdpl.2278-0238.2017.6(6).2806-2812

14.Kumari, A., Parida, A. K., Rangani, J. and Panda, A. (2017). Antioxidant activities, metabolic profiling, proximate analysis, mineral nutrient compositions of Salvadora persica fruit unravel a potential functional food and a natural source of pharmaceuticals. Frontiers in Pharmacology, 8, 61: https://doi.org/10.3389/fphar.2017.00 061.

15.Kumar, P., Kumar, V., Kumar, S., Singh, J. and Kumar, P. (2020). Bioethanol production from sesame (Sesamum indicum L.) plant residue by combined physical, microbial and chemical pretreatments. Bioresource Technology, 297: 122484. https://doi.org/10.1016/ j.biortech.2019.1224 84

16.Maatallah, S., Dabbou, S., Castagna, A., Guizani, M., Hajlaoui, H., Ranieri, A.M. and Flamini, G. (2020). Prunus persica by-products: A source of minerals, phe- nols and volatile compounds. Scientia Horticulturae, 261, 109016. https://doi.org/10.1016/j.scienta.2019.109016

17.Nakagawa, T., Allam, A.E., Ohnuki, K. and Shimizu, K. (2018). Biological Activities of Extracts from Different Parts of two Cultivars of Prunus persica 'Akatsuki'and 'Fastigiata'. Natural Product Communications, 13(10). https://doi.org/10.1177/1934578x1801301015

18.Qumar, N. (2016). Study of nutritional constituents and sensory evaluation of bakery products prepared from seed and bark of Prunus persica (Peach). International Journal of Research - Granthaalayah, 4 (6): 12-24.

19.Rani, S., Punia, P., Jamal, Z., Singh, V. and Goyal, S. (2016). Antimicrobial property of peach leaves. International Journal of Home Science. 2(3): 410-412.

20.Raturi, R., Singh, H., Bahuguna, P., Sati, S.C. and Badoni, P.P. (2011). Antibacterial and antioxidant activity of methanolic extract of bark of Prunus persica. Journal of Applied and Natural Science, 3(2): 312-314.https:// doi.org/10.31018/jans.v3i2.205

21.Shukla, R.K., Painuly, D., Porval, A. and Shukla, A. (2012). Proximate analysis, nutritive value, total phenolic content and antioxidant activity of Litchi chinensis Sonn. Natural Products: An Indian Journal, 8, 361-9.

22.Sivapriya, T. and John, S. (2019). Identification, isolation and elucidation of compounds from fraction of methyl hydroxyl chalcone polymer from aqueous extract of Cinnamomum zeylaynicum. Asian Journal of Pharmacy and Pharmacology, 5, 582-588. https://doi.org/10.31024/ ajpp.2019.5.3.22

23.Tungmunnithum, D., Thongboonyou, A., Pholboon, A. and Yangsabai, A. (2018). Flavonoids and other phenolic compounds from medicinal plants for pharmaceutical and medical aspects: An overview. Medicines, 5(3): 93.https:// doi.org/10.3390/medicines5030093

24.Victoria Ferna'ndez, Mohamed Khayet, Pablo MonteroPrado, Jose' Alejandro Heredia-Guerrero, Georgios Liakopoulos, George Karabourniotis; Vi'ctor del Rı'o, Eva Domı'nguez, Ignacio Tacchini, Cristina Nerı'n, Jesu's Val, and Antonio Heredia, (2019). New Insights into the Properties of Pubescent Surfaces: Peach Fruit as a Model. Plant physiology, 156 (4): 2098-2108. https:// doi.org/10.1104/pp.111.176305

25.Zhang, X., Li, X., Su, M., Du, J., Zhou, H., Li, X. and Ye, Z. (2020). A comparative UPLC-Q-TOF/MS-based metabolomics approach for distinguishing peach (Prunus persica (L.) Batsch) fruit cultivars with varying antioxidant activity. Food Research International, 109531.

26.Zhao, X., Zhang, W., Yin, X., Su, M., Sun, C., Li, X. and Chen, K. (2015). Phenolic composition and antioxidant properties of different peach [Prunus persica (L.) Batsch] cultivars in China. International Journal of Molecular Sciences, 16 (3): 5762-5778. https://doi.org/10.3390/ijms16 035762 